\title{
35. INTERSTITIAL WATER CHEMISTRY: DEEP SEA DRILLING PROJECT, LEG 11
}

\author{
B. J. Presley ${ }^{1}$ and I. R. Kaplan, Department of Geology and Institute of Geophysics and Planetary Physics, \\ University of California, Los Angeles, California.
}

\section{INTRODUCTION AND PROCEDURES}

The interstitial water received at UCLA from Leg 11 (Miami to Hoboken) consisted of fourteen samples of 5 millimeters each intended for carbon isotope and minor constituent work. No large volume samples for trace element work had been received when this report was written. The samples had been collected at six different drilling sites, and from a variety of sediment types.

All water was forced through a 0.45 -micron membrane filter on board ship immediately after squeezing. The samples were then sealed in plastic syringes, and were kept refrigerated, except for time in shipment. Analysis was started as soon as the samples arrived at UCLA; nevertheless, as much as three months had then elapsed since collection.

The analytical procedures currently being used in our pore water program are described in some detail elsewhere (Presley, 1971; Presley and Claypool, 1971). These procedures have evolved as we have sought to obtain more and better data from the small samples available from the Deep Sea Drilling Program. Therefore, the procedures used for Leg 11 may not be exactly as described in the references, but any changes are too minor to warrant mention here.

In addition to pore water, 20 samples of gas taken from Leg 11 sediments were sent to UCLA for analysis. These had been collected by puncturing gas pockets visible through the core liner, and allowing the gas to enter a sealed evacuated tube. Analytical work, including carbon isotope analysis, on these gases is now in progress, and will be reported elsewhere. We will, however, comment briefly in this report on the shipboard gas chromatography performed on these gases.

\section{RESULTS AND DISCUSSION}

All data that we have obtained to date from the water samples is given in Table 1 , except major cation concentrations, which were omitted since they can be found in the report by Manheim et al. (this volume). The $p \mathrm{H}$ determination made on board ship is also

\footnotetext{
${ }^{1}$ Present address: Department of Oceanography, Texas A \& M University, College Station, Texas 77843.
}

given, but the shipboard $\Sigma \mathrm{CO}_{2}$ values have been omitted, because, as on previous legs, the laboratory and shipboard values show moderately good agreement, and the laboratory values are more reliable.

The chloride and bromide values given in Table 1 were each determined on approximately 0.2 millimeter of water, and there was in no case a sufficient sample for replicate determinations. For this reason some scatter in the data is to be expected, and one might legitimately question an isolated odd number, such as, the high bromide in the only sample analyzed from Site 104. However, the values for nearby Site 102, where six samples were analyzed, present quite a different case. Here chloride and bromide are found in near-sea-water concentrations in the uppermost sample, but with increasing depth chloride shows a slight decrease in concentration, and bromide a very strong increase. This results in a chloride to bromide ratio of only 40 per cent-that of sea water at 424 meters depth. Our deepest sample from this site came from a depth of 619 meters, and it had more chloride and less bromide than the sample from 424 meters. Thus, the sediment responsible for the extremely low chloride to bromide ratios must be between these depths.

Other constituents-for example, boron, silica, ammonia, and manganese-also show concentrations at a depth of 619 meters which contrast with smooth trends established in shallower samples. This adds confidence to the chloride and bromide values and must indicate some fundamental but unknown change in sediment type or environment somewhere between 424 and 619 meters into the sediment column.

It is unfortunate that we did not receive more samples from Holes 103 and 104 in order to more clearly delineate the changes found at Site 102. This cluster of three holes was drilled into rather unusual sediments containing abundant organic matter which has led to sulfate reduction and pyrite formation. Siderite and other authigenic minerals were also reportedly common. We have asked the Manheim group to analyze the samples they received from Holes 103 and 104 for bromide, and perhaps when their work is completed, and more data is available on mineralogy, some mechanisms for production of this unusual pore water can be suggested. At present we can do little more that point out the phenomenon. 
TABLE 1

Selected Major and Minor Constituents and $\mathrm{C}^{13}$, Interstitial Water, Leg 11

\begin{tabular}{|c|c|c|c|c|c|c|c|c|c|c|c|c|}
\hline $\begin{array}{l}\text { Sample } \\
\text { Number }\end{array}$ & $\begin{array}{c}\text { Depth }^{b} \\
\text { (m) }\end{array}$ & Age and Description of Sediment ${ }^{\mathrm{C}}$ & $\begin{array}{c}\mathrm{C} 1 \\
(\mathrm{~g} / \mathrm{kg})\end{array}$ & $\begin{array}{c}\mathrm{Br} \\
(\mathrm{mg} / \mathrm{kg})\end{array}$ & $\begin{array}{c}\mathrm{B} \\
(\mathrm{mg} / \mathrm{kg})\end{array}$ & $\begin{array}{c}\mathrm{Si} \\
(\mathrm{mg} / \mathrm{kg})\end{array}$ & $\begin{array}{c}\mathrm{NH}_{3} \\
(\mathrm{mg} / \mathrm{kg})\end{array}$ & $\begin{array}{c}\mathrm{Mn} \\
(\mathrm{mg} / \mathrm{kg})\end{array}$ & $\begin{array}{c}\mathrm{Li} \\
(\mathrm{mg} / \mathrm{kg})\end{array}$ & $\begin{array}{l}\sum_{(\mathrm{mM} / \mathrm{kg})}{ }^{\mathrm{d}} \\
\end{array}$ & $\begin{array}{l}\delta \mathrm{C}^{13} \\
(\mathrm{PDB})\end{array}$ & $\mathrm{PH}^{\mathrm{e}}$ \\
\hline $99 \mathrm{~A}-1-4$ & 5 & Pleistocene clayey foram-nanno ooze & 19.2 & 66 & - & 6.6 & 7.0 & $<0.20$ & 0.19 & 2.24 & - & 7.4 \\
\hline $101-2-3$ & 73 & Late Miocene hemipelagic clay, pyrite streaks & 19.3 & 64 & 4.7 & 10.9 & 24.3 & 0.72 & 0.37 & 11.00 & -15.3 & 7.7 \\
\hline $101 \mathrm{~A}-1-3$ & 123 & Middle Miocene hemipelagic clay, pyrite and siderite & 19.7 & 64 & 3.9 & 16.0 & 38.5 & 0.69 & 0.43 & 10.80 & -19.7 & 7.7 \\
\hline $101 \mathrm{~A}-3-2$ & 202 & Middle Miocene hemipelagic clay, pyrite and siderite & 19.7 & 64 & 4.9 & 7.1 & 22.5 & 0.73 & 0.39 & 6.08 & -17.1 & 7.7 \\
\hline $102-1-5$ & 6 & Pleistocene hemipelagic mud with black Fe sulfide & 19.1 & 66 & 5.4 & 19.0 & 16.0 & 2.00 & 0.14 & 18.40 & -26.4 & - \\
\hline $102-2-5$ & 25 & Pleistocene hemipelagic mud, diatoms, Fe sulfide, pyrite & 19.3 & 74 & 6.4 & 19.8 & 10.5 & 0.82 & 0.11 & 23.50 & -21.8 & 7.8 \\
\hline $102-4-4$ & 101 & Pleistocene hemipelagic mud, nanno-fossils, Fe sulfide & 19.4 & 89 & 4.8 & 14.9 & 14.5 & $<0.20$ & 0.15 & 16.20 & -1.1 & 7.9 \\
\hline $102-7-5$ & 187 & Early Pleistocene hemipelagic clay, $\mathrm{SiO}_{2}, \mathrm{CaCO}_{3}$ fossils & 19.1 & 110 & 3.6 & 22.3 & 47.0 & $<0.20$ & 0.20 & 12.40 & +3.0 & 8.1 \\
\hline $102-12-4$ & 424 & Middle Pliocene firm hemipelagic clay, nannofossils, siderite & 18.3 & 160 & 1.5 & 10.2 & 170.0 & $<0.20$ & 0.59 & 5.65 & -0.8 & 7.9 \\
\hline $102-17-1$ & 619 & Late Miocene indurated clay, nannofossils, pyrite & 19.1 & 100 & 2.9 & 17.4 & 72.0 & 0.45 & 0.80 & 4.54 & +1.2 & 7.4 \\
\hline $103-1-5$ & 7 & Early Pliocene firm green hemipelagic mud, $\mathrm{H}_{2} \mathrm{~S}, \mathrm{FeS}$ & 18.9 & 66 & - & 6.5 & 2.6 & 0.55 & 0.18 & 3.11 & -16.7 & 7.9 \\
\hline $104-2-5$ & 44 & Middle Miocene soft hemipelagic mud, $\mathrm{H}_{2} \mathrm{~S}, \mathrm{FeS}_{2}$ & 19.3 & 77 & - & 14.2 & 6.3 & $<0.20$ & 0.54 & 21.30 & -19.9 & 7.5 \\
\hline $106-1-2$ & 2 & Quaternary soft hemipelagic mud, FeS layers & 19.1 & 66 & 5.5 & 16.1 & 3.5 & 3.75 & 0.16 & 4.54 & -8.5 & 7.5 \\
\hline $106-3-4$ & 115 & Early Pleistocene soft clay with green sand & 19.1 & 71 & 5.2 & 11.6 & 40.0 & $<0.20$ & 0.12 & 7.08 & -11.3 & 8.0 \\
\hline \multicolumn{3}{|c|}{ Average Sea Water } & 19.4 & 67 & 4.5 & $0-3$ & $0(?)$ & 0.002 & 0.17 & 2.60 & 0.0 & 8.1 \\
\hline
\end{tabular}

${ }^{\mathrm{a}}$ Hole, core, section.

${ }^{b}$ Depth in sediment column.

${ }^{\mathrm{c}}$ From preliminary hole summaries.

${ }^{d}$ Laboratory measurement.

${ }^{\mathrm{e}}$ Shipboard measurement. 
An easily detectable amount of ammonia was present in all samples received from Leg 11; this is in itself an unusual circumstance. Furthermore, the ammonia in many samples accounted for a considerable percentage of the total alkalinity. In fact, the sample at 424 meters depth in Hole 102 has more than twice as much ammonia $\left(\mathrm{NH}_{3}\right)$ as dissolved carbonate on a molar basis. In the decomposition of organic matter, more than six times as much carbon dioxide $\left(\mathrm{CO}_{2}\right)$ as ammonia $\left(\mathrm{NH}_{3}\right)$ should be produced. It thus appears that large amounts of carbon dioxide have been removed from the pore water. Much of this probably went into authigenic carbonates; we find calcium to be greatly depleted in these waters (see also the chapter by Manheim et al., this volume), and authigenic siderite is a common component of the sediment.

The tendency for carbon-dioxide depletion at depth in the sediment column has been noted at many of the sites from previous legs. However, this loss is usually accompanied by an increase rather than a decrease in calcium concentration. This seems most likely to result from a breakdown or leaching of silicates which releases calcium and supersaturates the pore water with respect to $\mathrm{CaCO}_{3}$ or perhaps dolomite. The formation of authigenic dolomite would also explain the commonly observed decrease in magnesium concentration. The opposite effect, that is, excess of carbon dioxide and resulting calcium depletion occurs only where organic matter is abundant and is being biologically degraded.

The high ammonia concentration seems not to have greatly affected the $p \mathrm{H}$ of the pore waters. This observation has been made before, and a discussion of the effects of metabolic products on pore water $p \mathrm{H}$ can be found in Presley (1969), and in an expanded and slightly modified form in Ben-Yaakov (in preparation).

The $\delta C^{13}$ values at shallow depths where very high concentrations of total dissolved carbon dioxide are found show a strong biological influence as we have noted in previous studies (Presley and Kaplan, 1968). Furthermore, the tendency noted on previous legs for the dissolved carbon dioxide to become isotopically heavier with depth is very clearly shown at Sites 101 and 102. When more samples are analyzed, and when isotope work on the solid phases is conducted, the mechanism for this light isotope depletion with depth may be determined. At present we can only suggest that it is most likely related to exchange with solid carbonate phases and dissolved hydrocarbon gases.

The interstitial gas determinations made on board ship have been summarized in Table 2. These values were obtained by simply summing the peak heights shown on the chromatograms and finding what percentage of that sum is accounted for by each individual peak. This assumes that the chromatograph is equally sensitive to
TABLE 2

Shipboard Analysis of Gases Released by Leg 11 Sediment

\begin{tabular}{lclcccc}
\hline Sample & $\begin{array}{c}\text { Depth } \\
(\mathrm{m})\end{array}$ & Age & $\begin{array}{c}\text { "Air" } \\
\%\end{array}$ & $\begin{array}{c}\mathrm{CH}_{4} \\
\%\end{array}$ & $\begin{array}{c}\mathrm{C}_{2} \mathrm{H}_{6} \\
\%\end{array}$ & $\begin{array}{c}\mathrm{CO}_{2} \\
\%\end{array}$ \\
\hline $103-3$ & 100 & Late Miocene & 48 & 51 & 0.01 & 0.5 \\
$103-4$ & 175 & Late Miocene & 36 & 63 & 0.01 & 1.1 \\
$103-5$ & 252 & Middle Miocene & 41 & 58 & 0.02 & 0.6 \\
& & & & & & \\
$104-2$ & 40 & Middle Miocene & 44 & 53 & 0.01 & 2.2 \\
$104-3$ & 67 & Middle Miocene & 26 & 72 & 0.01 & 1.8 \\
$104-4$ & 138 & Middle Miocene & 38 & 61 & 0.01 & 2.6 \\
$104-6$ & 224 & Middle Miocene & 39 & 59 & 0.03 & 2.4 \\
$104-7$ & 300 & Middle Miocene & 41 & 57 & 0.04 & 1.9 \\
$104-8$ & 405 & Middle Miocene & 40 & 56 & 0.03 & 3.5 \\
$104-9$ & 500 & Middle Miocene & 41 & 56 & 0.04 & 3.2 \\
& & & & & & \\
$106 \mathrm{~B}-2$ & 455 & Early Pliocene & 42 & 58 & 0.01 & 0.3 \\
$106 \mathrm{~B}-4$ & 760 & Middle Miocene & 44 & 50 & 0.04 & 0.5 \\
$106 \mathrm{~B}-5$ & 940 & Middle Miocene & 58 & 41 & 0.05 & 1.0 \\
\hline
\end{tabular}

all gases, and should therefore be considered only a rough estimate of the actual composition of the injected gas. Furthermore, the injected gas may be quite different from the actual sample gas, because in this procedure there is no provision for either knowing or controlling the pressure of the gas. Thus, if the gas is under a reduced pressure, air will be sucked into the sampling syringe and become part of the injected sample.

A few samples have now been injected into a chromatograph for oxygen determination. If we make the reasonable assumption that this oxygen represents atmospheric contamination during sampling, the air peaks shown by the shipboard chromatograph are considerably too high. An adjustment would, however, little affect the $\mathrm{CH}_{4}$ to $\mathrm{C}_{2} \mathrm{H}_{6}$ to $\mathrm{CO}_{2}$ ratios, which are the primary concern in this study. These ratios have now been determined in the laboratory for a few samples, and in general give values close to those in Table 2. This laboratory data will be reported in detail when the analyses are completed.

This preliminary work on the interstitial gases shows the Leg 11 samples to be somewhat richer in $\mathrm{CO}_{2}$ than those from Leg 10, and to contain much less $\mathrm{C}_{2} \mathrm{H}_{6}$ than some of the Leg 10 samples.

The silicon values shown in Table 1 are probably too high due to a temperature of squeezing effect, but it is not possible at this time to estimate the magnitude of the effect. The values found here are similar to those found on previous legs, being much higher than sea water, and approaching saturation with respect to amorphous silica where it is reportedly abundant. 
Lithium concentrations have typically increased with depth in the sediment column at previous sites, and a very strong enrichment was found in the deepest samples analyzed from Leg 11. However, at Site 102 a lithium depletion was found at intermediate depths, a phenomenon for which we have no explanation. Boron was also depleted at depth at this site, as it has been at a number of sites on previous legs.

Manganese, as usual, is highly and unpredictably variable in concentration. Site 106 gives yet another example of a phenomenon which we have pointed out many times, that is, a high dissolved manganese concentration in reducing sediments at greater depth. This once again shows that the often proposed model of manganese mobilization at depth, and an upward migration and precipitation, appears to be unworkable in many environments.

\section{ACKNOWLEDGEMENTS}

This work was supported in part by AEC Grant AT(11-1)-34 P.A. 134 and NSF Grant GA-20715. Valuable laboratory assistance was provided by Chari
Petrowski and George Claypool. We thank these individuals and agencies.

\section{REFERENCES}

Presley, B. J. and Kaplan, I. R., 1968. Changes in dissolved sulfate, calcium and carbonate from interstitial water of nearshore sediments. Geochim. Cosmochim. Acta, 32, 1037.

Presley, B. J., 1969. Chemistry of interstitial water from marine sediments. Ph.D. Dissertation, UCLA.

Presley B. J., 1971. Techniques for analyzing interstitial water samples, Part I: Determination of selected minor and major inorganic constituents. In E. L. Winterer et al., 1971. Initial Reports of the Deep Sea Drilling Project, Volume VII. Washington (U.S. Government Printing Office).

Presley, B. J. and Claypool, G. E., 1971. Techniques for analyzing interstitial water samples, Part II: Determination of total dissolved carbonate and carbon isotope ratios. In E. L. Winterer et al., 1971. Initial Reports of the Deep Sea Drilling Project, Volume VII. Washington (U. S. Government Printing Office). 